\title{
Poly A:U-Induced Secretion of T-Lymphocyte Helper Factors
}

\author{
P. H. BICK \& A. G. JOHNSON \\ Department of Microbiology, University of Michigan Medical School, \\ Ann Arbor, Michigan, USA
}

\begin{abstract}
Bick, P. H. \& Johnson, A. G. Poly A:U-Induced Secretion of T-Lymphocyte Helper Factors. Scand. J. Immunol. 6, 1133-1144, 1977.

In vitro exposure of mouse thymocytes to complexes of polyadenylic:polyuridylic acid (poly A:U) effected, within $6 \mathrm{~h}$, the release of soluble factor(s) capable of nonspecifically enhancing IgM and IgG plaque-forming cells (PFCs) in in vitro primary and secondary spleen cell responses to burro erythrocytes. Poly A:U stimulation was, most likely, polyclonal, since production of soluble factor(s) occurred in the absence of antigen and in serum-free culture media. Poly A:Uinduced soluble factor(s) were not capable of substituting for $\mathrm{T}$ cells but were dependent on $T$ cells for the expression of PFC enhancement. These data support the hypothesis that the mechanism of poly A:U's adjuvant action is polyclonal stimulation of $T$ cells, causing early induction and release of nonspecific, soluble PFC-enhancing factor(s).

A. G. Johnson, Department of Microbiology, University of Michigan Medical School, 6643 Medical Sciences Bldg. II, Ann Arbor, MI 48109, USA
\end{abstract}

Complexes of polyadenylic-polyuridylic acid (poly A:U) have been shown to be effective adjuvants to both limbs of the immune response (18). Although several cells are affected by this adjuvant, a major effect is exerted on the $T$ cell. This was most clearly manifested when the number of $T$ cells was diminished by thymectomy or anti-lymphocyte globulin (3). It seemed likely that this adjuvant amplified the efficiency of residual $T$ cells. Indirect evidence supporting this view was gained by means of experiments showing that vinblastine, a drug that inhibits cell division, reduced antibody synthesis in poly $\mathrm{A}: \mathrm{U}$ treated mice by $90 \% 6 \mathrm{~h}$ before mice receiving only antigen (4). Direct evidence that poly $A: U$ was acting on thymocytes was achieved through the use of the irradiated mouse model (3). In these experiments, in which either thymocytes or bone marrow cells were selectively incubated in vitro with or without poly
A: $U$ before transfer, a tenfold increase in rosette-forming cells occurred in mice receiving thymocytes incubated with poly A:U. Furthermore, by reducing the number of thymocytes to 40,000 , an amount far below the minimal threshold number necessary to act as helper cells for antibody synthesis, a response was elicited after incubation with poly $A: U$, again suggesting amplification of $\mathrm{T}$-cell function. $\mathrm{B}$ cells selectively exposed to poly $A: U$ in a similar manner did not increase their activity to form rosettes, although polynucleotides have been shown to be mitogenic for these cells (22, 23). In addition, low numbers of thymocytes incubated with poly $A: U$ in vitro reconstituted the antibody response of nude mouse spleen cell cultures, whereas normal control thymocytes did not (5).

Although the experiments suggested that poly $A: U$ acted by stimulating division of $T$ lymphocytes, extensive study indicated that this 
adjuvant was not mitogenic for thymus cells over a wide dose range (16). In addition, poly $\mathrm{A}: \mathrm{U}$ was only weakly mitogenic for spleen cells when 1-5 $\mu \mathrm{g}$ was given intravenously to normal or cortisone-treated Balb mice. Similarly, only a doubling of control values was evident in vitro when poly $A: U$ was added to cultures of spleen cells from normal or cortisone-treated mice. Thus, a weak mitogenic effect of poly A:U appeared to be exerted on peripheral $T$ cells, but there was no effect on thymocytes per se (16). Consequently, we have further studied the mechanism of the profound adjuvant action of poly A:U. Since $T$ cells have been shown to be capable of producing soluble factors that enhance antibody responses in vivo and in vitro after antigen stimulation (1, $12,13,21,24,27,31$ ), we tested the hypothesis that the observed thymocyte helper activity might be mediated through the release of a soluble factor(s), the secretion of which can be snhanced or increased in amount by poly $A: U$ action on $T$ cells. The experimental evidence presented here supports this hypothesis.

\section{MATERIALS AND METHODS}

Experimental animals. $(\mathrm{C} 57 \mathrm{Bl} / 6 \times \mathrm{C} 3 \mathrm{Hf}) \mathrm{F}_{1}$ hybrids were purchased from Microbiological Associates, Bethesda, Md., USA, or raised in our laboratory colony from inbred $\mathrm{C} 57 \mathrm{Bl} / 6$ female and $\mathrm{C} 3 \mathrm{Hf}$ male parents obtained from Microbiological Associates. Balb/aj mice were inbred in our laboratory colony. Mice were ageand sex-matched for each experiment. Nude mice on a Balb/c background were a gift of Dr. Norman Reed, Montana State University, and were used at 10-12 weeks of age as spleen cell donors. (C57Bl/6 $\times \mathrm{C}_{3} \mathrm{Hf}$ ) $\mathrm{F}_{1}$ and Balb/aj mice used for donors of thymocytes were killed at 4-6 weeks of age, whereas those used as spleen cell donors were killed at 12-20 weeks of age.

Antigens. Sheep erythrocytes (SRBC) were obtained by monthly bleedings of a single sheep donor maintained in the University of Michigan School of Public Health and were stored in $50 \%$ Alsever's solution at $4{ }^{\circ} \mathrm{C}$ for 4 weeks before use. Burro erythrocytes (BRBC) were obtained from Colorado Serum Co., Denver, Colo,, as sterile burro blood in Alsever's solution. They were stored at $4^{\circ} \mathrm{C}$ and used at 2-7 weeks of age. Before use, SRBCs and BRBCs were washed three times in Möller's modified balanced salt solution (MSS) (6) and resuspended in the appropriate menstrum to yield approximately $2.4 \times 10^{8} \mathrm{RBC}$ $\mathrm{ml}$.

Homopolyribonucleotides. Polyadenylic acid (lots 67, 77, 81) and polyuridylic acid (lots $72,77,91$ ) were purchased as the potassium and ammonium salts, respectively, from Miles Laboratories Research Products Division, Kankakee, Ill. Tritium-labeled polyadenylic acid (lot 13) was obtained from Miles Laboratories in 50\% ethanol solution and had a specific activity of $19.1 \mu \mathrm{Ci} / \mathrm{mg}$ polymer. The homoribopolymers were dissolved in phosphate-buffered saline (PBS), $\mathrm{pH} 7.2$, at a concentration of not less than $5 \mathrm{mg} / \mathrm{ml}$ and sterilized by filtration through a filter of $0.22-\mu \mathrm{m}$ pore size (Millipore Corp., Bedford, Mass.). Radiolabeled polyadenylic acid was not filter-sterilized. Poly $A: U$ complexes were prepared by aseptically combining equal amounts of the individual homoribopolymers at a concentration not less than $5 \mathrm{mg} / \mathrm{ml}$ (final concentration of each polymer, $2.5 \mathrm{mg} / \mathrm{ml}$ ). The mixture was allowed to complex for at least $10 \mathrm{~min}$ at room temperature, and dilutions were made in PBS to yield the desired concentrations. Sterile preparations of the homoribopolymers were stored at $-20^{\circ} \mathrm{C}$, whereas complexed poly $\mathrm{A}: \mathrm{U}$ was stored at $4^{\circ} \mathrm{C}$.

Lipopolysaccharide. Lipopolysaccharide (LPS) from Serratia marcescens, prepared by the Boivin procedure, was a gift of Dr. A. Nowotny, Temple University, Philadelphia, Pa.

Antisera. Anti-theta antisera, anti-Thy 1.2, were prepared by the method of Reif \& Allen (20). The 50\% cytotoxicity titer against $F_{1}$ thymocytes was $1: 600$, both by ${ }^{51} \mathrm{Cr}$ release and trypan blue determination. A dilution of 1:50 or less was used routinely, which killed $97 \%$ of thymocytes. All anti-theta activity was removed by absorption with $\mathrm{C} 3 \mathrm{H}$ brain cells. Background cytotoxicity levels with anti-theta antiserum and thymus cells alone were routinely 
$5 \%$ or less by both techniques and were below the cytotoxicity levels of cells incubated alone. Rabbit anti-mouse IgG facilitating indirect plaque-forming cells (PFC) was prepared by Dr. Carl Pierce, Harvard Medical School, Boston, Mass.

Complement. Complement (GPC) was obtained from guinea pigs that were ether-anesthetized and bled by heart puncture. GPC to be used for PFC assay was absorbed twice for $30 \mathrm{~min}$ with RBCs and immediately frozen at $-70^{\circ} \mathrm{C}$ in multiple tubes for individual experiments. GPC to be used for cell depletion and cytotoxicity assays was absorbed with agarose and mouse spleen cells. All complement sera were thawed only once before use and had a cytotoxicity titer of $1: 128-1: 256$ as determined by titration with $\left(\mathrm{C} 57 \mathrm{Bl} / 6 \times \mathrm{C}_{3} \mathrm{Hf}\right) \mathrm{F}_{1}$ thymocytes and anti-theta antiserum using the trypan blue cytotoxicity assay. Background cytotoxicity of GPC without anti-theta antiserum was negligible.

Cell preparations. Thymus and spleens were aseptically removed from mice killed by cervical dislocation, kept in MSS on ice, and teased apart, and the large debris was removed after being allowed to settle. The cells in suspension were pelleted by centrifugation for $10 \mathrm{~min}$ at $200 \mathrm{~g}$ at $6^{\circ} \mathrm{C}$. Viability was determined by trypan blue dye exclusion and was routinely greater than $95 \%$.

In vitro culture methods. Culture conditions were essentially those of Mishell \& Dutton (19) with the addition of $10 \mathrm{mM}$ Hepes and $5 \times 10^{-5} \mathrm{M}$ 2-mercaptoethanol. Culture medium was supplemented with heat-inactivated fetal calf serum (FCS) at $10 \%$ final concentration when appropriate (Reheis, Lot 22803, Armour Pharmaceutical Co., Phoenix, Ariz.). Cells were cultured at a density of $10^{7} / \mathrm{ml}$ in $35 \times 10-\mathrm{mm}$ plastic culture dishes. Where appropriate, $10^{7} \mathrm{SRBC}$ or $\mathrm{BRBC}$ were added per dish as antigen. Culture dishes were incubated in a gas-tight humidified chamber containing $7 \% \mathrm{O}_{2}, 10 \% \mathrm{CO}_{2}$, and $83 \% \mathrm{~N}_{2}$ and were rocked at approximately 7 cyclesimin at $37^{\circ} \mathrm{C}$.

Antibody-forming cell assay. Plaque-forming cells were assayed by the local hemolysis-in-gel technique of Jerne \& Nordin as modified by Coutinho et al. (7). Indirect (IgG) PFCs were determined by plating a second sample of a given cell suspension using GPC that contained rabbit anti-mouse IgG (1:100 final dilution in GPC). Since the facilitating antisera caused no inhibition of the IgM PFCs during the assay, the number of IgG PFCs was determined directly by subtraction of total direct PFCs from total indirect PFCs. After correction for viable recovered cells, $\log _{10}$ PFCs were calculated. To determine the level of confidence at which two values were significantly different, the mean \pm standard error for each group was calculated from the results of three normalized experiments and compared using Student's $t$ test. Two groups were considered significantly different when $P$ was less than 0.05 . Normalization was carried out by setting the PFC response to antigen alone at $100 \mathrm{PFC}$ $10^{6}$ viable recovered cells and adjusting all other values in the same experiment accordingly. Subsequently, several experiments could be pooled for statistical evaluation. This procedure was adopted because antigen-induced responses to $B R B C$ were reproducibly in the range of 50-150 PFC/106 viable recovered cells.

Preparation of supernatant fluids. Lymphocytes were incubated for $10-30 \mathrm{~min}$ in FCSfree culture media $\left(10^{7}\right.$ cells $\left./ \mathrm{ml}\right)$ with or without poly $A: U$ in plastic centrifuge tubes in a shaking $37^{\circ} \mathrm{C}$ water bath. After incubation, cell mixtures were immediately washed four times and centrifuged at $200 \mathrm{~g}$ for $10 \mathrm{~min}$ at $6^{\circ} \mathrm{C}$ after each wash. After the washing, cells were resuspended in fresh FCS-free culture media and cultured for 0-24 h (usually $6 \mathrm{~h}$ ) under standard culture conditions. Supernatant fluids were decanted into glass centrifuge tubes and intact cells pelleted at $200 \mathrm{~g}$ for $10 \mathrm{~min}$ at $6^{\circ} \mathrm{C}$. Any remaining large particulate matter was removed by centrifugation at $20,200 \mathrm{~g}$ for $20 \mathrm{~min}$ at $6^{\circ} \mathrm{C}$. Supernatant fluids were sterilized by filtration through a Millipore membrane of $0.22-\mu \mathrm{m}$ pore size and assayed immediately. Any remaining fluid was stored at $4^{\circ} \mathrm{C}$.

Assay of supematant fluids. Supernatant fluids were assayed for PFC-enhancing activity 
Table I. Polyadenylic:polyuridylic acid (poly A:U) stimulation of mouse thymocytes: dose response

\begin{tabular}{|c|c|c|c|c|c|}
\hline \multirow[b]{2}{*}{ Group } & \multicolumn{3}{|c|}{$(\mathrm{C} 57 \mathrm{Bl} / 6 \times \mathrm{C} 3 \mathrm{Hf}) \mathrm{F}_{1}$ spleen cells $\left(10^{7}\right)$ plus } & \multicolumn{2}{|c|}{$\begin{array}{c}\log _{10} \operatorname{IgM} P F C / 10^{6} \text { viable recovered } \\
\text { spleen cells }\end{array}$} \\
\hline & Antigen & $\begin{array}{l}\text { Poly A:U } \\
(\mu \mathrm{g} / \mathrm{ml})\end{array}$ & $\begin{array}{l}\text { Thymocyte supernatant } \\
\text { fluids }(\mu \mathrm{g} / \mathrm{ml} \mathrm{A}: \mathrm{U})\end{array}$ & $\begin{array}{l}\text { Expt. } 1^{*} \\
\text { SRBC }\end{array}$ & $\begin{array}{l}\text { Expt. } 2 \dagger \\
\text { BRBC }\end{array}$ \\
\hline 1 & - & - & - & $2.21(161)$ & $0.95(9)$ \\
\hline 2 & + & - & - & $2.98(977)$ & $2.00(100)$ \\
\hline 3 & + & 1.0 & - & $3.50(3177)$ & - \\
\hline 4 & + & 0.1 & - & - & $2.03(108)$ \\
\hline 5 & + & - & 0 & $2.88(761)$ & $1.67(47)$ \\
\hline 6 & + & - & 1.0 & - & $1.74(55)$ \\
\hline 7 & + & - & 5.0 & $2.85(707)$ & - \\
\hline 8 & + & - & 10.0 & - & $2.27(188)$ \\
\hline 9 & + & - & 50.0 & $3.32(2127)$ & $2.39(251)$ \\
\hline 10 & + & - & 100.0 & - & $2.18(154)$ \\
\hline 11 & + & - & 500.0 & $3.09(1231)$ & $2.12(133)$ \\
\hline
\end{tabular}

* Normal $F_{1}$ thymocytes $\left(10^{7} / \mathrm{ml}\right)$ were incubated with $50 \mu \mathrm{g} / \mathrm{ml}$ poly A:U for 90 min, washed four times, and cultured for $24 \mathrm{~h}$. Supernatant fluids were added to cultures of normal $F_{1}$ spleen cells at a $1: 4$ final dilution with sheep erythrocytes (SRBC) as antigen on day 0. Plaque-forming cells (PFCs) were assayed on day 4. Antilog PFC values are presented in parentheses.

$\dagger$ As above, except that the thymocytes were incubated with poly A:U for $10 \mathrm{~min}$ and cultured for $6 \mathrm{~h}$. Burro erythrocytes (BRBC) were used as antigen in this experiment.

in $F_{1}$, Balb/aj, or Balbjc nu/nu spleen cell cultures. Triplicate cultures were prepared in FCS containing culture media at a density of $10^{7}$ cells,ml and maintained under standard culture conditions. Supernatant fluids were added on day 0 at a $1: 4$ final dilution $(0.25 \mathrm{ml}$ supernatant fluid/1.0 $\mathrm{ml}$ culture) unless otherwise indicated. $10^{7} \mathrm{SRBC}$ or $\mathrm{BRBC}$ were added to appropriate cultures on day 0 . Poly A:U was added with antigen in selected groups as a positive control. Cultures in each group were pooled on day 4 and assayed for PFCs.

\section{EXPERIMENTAL RESULTS}

In preliminary experiments (C57Bli6 $\times$ $\mathrm{C} 3 \mathrm{H}) \mathrm{F}_{1}$ thymocytes were exposed to lethally irradiated allogeneic (Balb/aj) spleen cells with or without poly $A: U$ in vitro and the supernatant fluids tested for their ability to enhance the PFC response to erythrocytes. Poly A:Uinduced supernatant fluids had only a slight effect above that induced by allogeneic stimulation alone. However, supernatant fluids from thymo- cytes stimulated with poly $A: U$ alone, in the absence of allogeneic cells, caused significant PFC enhancement in primary spleen cell cultures. This finding was pursued further, and optimal conditions for supernatant fluid production and assay were established. Normal $F_{1}$ thymocytes $\left(10^{7} / \mathrm{ml}\right)$ were incubated with various doses of poly $A: U$ for 10 or $90 \mathrm{~min}$, washed extensively, and cultured for 6 or 24 $h$, respectively. Harvested supernatant fluids were sterilized by filtration and assayed on day 0 by addition at a final dilution of $1: 4$ to $10^{7}$ normal, syngeneic spleen cells with $B R B C$ or SRBC as antigen. Direct PFCs were assayed 4 days later. As can be seen in Table I, cultures of poly A:U-stimulated thymocytes produced PFC-enhancing supernatant fluids in the absence of FCS or antigen. The supernatant fluids resulting from stimulation of thymocytes with $50 \mu \mathrm{g}$ poly $\mathrm{A}: \mathrm{U}$ for as short a time as $10 \mathrm{~min}$, followed by culture of the washed thymocytes for $6 \mathrm{~h}$, were capable of a 2.5 -fold enhancement of IgM PFC. Increased PFC responses of normal spleen cells to erythrocytes of two species suggested that poly A:U-induced super- 
Table II. Kinetics of polyadenylic:polyuridylic acid (poly A:U)-induced supernatant fluid (AUSF) production by poly A:U-stimulated thymocytes*

\begin{tabular}{|c|c|c|c|c|c|}
\hline \multirow[b]{2}{*}{ Group } & \multicolumn{3}{|c|}{$\left(\mathrm{C} 57 \mathrm{Bl} / 6 \times \mathrm{C}_{3} \mathrm{Hf}\right) \mathrm{F}_{1}$ spleen cells $\left(10^{7}\right)$ plus } & \multicolumn{2}{|c|}{$\begin{array}{c}\text { Mean } \log _{10} \mathrm{PFC} / 10^{6} \text { viable recovered } \\
\text { spleen cells }\end{array}$} \\
\hline & $\mathrm{BRBC}$ & $\begin{array}{l}\text { Thymocyte super } \\
\text { culture period }\end{array}$ & $\begin{array}{l}\text { natant fluids; } \\
\text { in hours }\end{array}$ & PFC & $P$ \\
\hline 1 & - & - & & $0.71 \pm 0.15(5)$ & \\
\hline 2 & + & - & & $2.00 \pm 0 \quad(100)$ & $<0.05 \dagger$ \\
\hline 3 & + & $\mathrm{CSF}$ & $0^{*}$ & $2.13 \pm 0.14(135)$ & n.s. ${ }^{* *}$ \\
\hline 4 & + & AUSF & $0^{*}$ & $2.11 \pm 0.12(129)$ & n.s. ${ }^{* *}$ \\
\hline 5 & + & CSF & 6 & $1.97 \pm 0.08$ & n.s. ${ }^{* *}$ \\
\hline 6 & + & AUSF & 6 & $2.48 \pm 0.09(302)$ & $<0.05+\dagger$ \\
\hline 7 & + & CSF & 12 & $2.28 \pm 0.04(190)$ & $<0.05^{* *}$ \\
\hline 8 & + & AUSF & 12 & $2.40 \pm 0.05(251)$ & $<0.001^{* *}, 0.05^{* * *}$ \\
\hline 9 & + & $\operatorname{CSF}$ & 18 & $2.23 \pm 0.35(170)$ & n.s. ${ }^{* *}$ \\
\hline 10 & + & AUSF & 18 & $2.45 \pm 0.13(282)$ & $<0.05^{* *}$ \\
\hline
\end{tabular}

* Normal $\mathrm{F}_{1}$ thymocytes were incubated with (AUSF) or without (control supernatant fluid; CSF) $100 \mu \mathrm{g} /$ $\mathrm{ml}$ poly $\mathrm{A}: \mathrm{U}$ for $10 \mathrm{~min}$, washed four times, and cultured for various periods of time. Supernatant fluids were added to cultures of normal $F_{1}$ spleen cells at a $1: 4$ final dilution with burro erythrocytes (BRBC) as antigen on day 0 . Direct plaque-forming cells (PFCs) were assayed on day 4. Normalized and pooled results of three experiments are shown. Antilog PFC values are presented in parentheses.

$\dagger$ Compared with group 1.

** Compared with group 2 ; n.s. $=$ not significant.

$\dagger \dagger$ Compared with groups 2 and 5.

$* * *$ Compared with group 7.

natant fluids (AUSF) both acted and were induced nonspecifically. BRBCs were chosen as the assay antigen for all subsequent experiments because the background $P F C$ response was lower to BRBC than to SRBC (allowing for greater sensitivity in the determination of PFC enhancement).

Titration of supernatant fluid activity indicated that different lots of AUSF varied in activity. A dilution of $1: 4$ produced a good response in most instances and was used in most experiments. However, occasional lots of AUSF gave essentially maximal responses at dilutions of $1: 200$.

\section{Kinetics of poly A:U-induced tbymocyte supernatant fluid production}

In other studies of soluble factors from $\mathrm{T}$ cells not induced by poly $A: U$, optimal enhancement usually appeared after 1-2 days in culture (32). To determine whether poly $A: U$ altered the kinetics of enhancing-factor production by thymocytes, normal $F_{1}$ thymocytes $\left(10^{7} / \mathrm{ml}\right)$ were incubated with poly $A: U$ for $10 \mathrm{~min}$, washed four times, and cultured for various periods of time.

Poly A:U stimulated the appearance of enhancing factors after only $6 \mathrm{~h}$ in culture (Table II). Normal, nonstimulated thymocytes also elaborated enhancing factors, but only after 18$24 \mathrm{~h}$ in culture. Supernatant fluids harvested immediately after exposure to poly A:U ( 0 time) did not contain enhancing activity.

No significant differences in viability were observed between control and poly A:U-stimulated thymocytes at any time period. Viabilities were consistently in the range of $90 \%-95 \%$ in the 6-h interval. The appearance of enhancing activity in AUSF was therefore not due to poly A:U-induced cytotoxicity. An overall rate of $1 \%-2 \%$ in loss in viability was observed for thymocytes in this system.

\section{Enbancement of IgM PFC in vitro by AUSF}

To compare statistically the levels of IgM PFC enhancement with different lots of AUSF, 


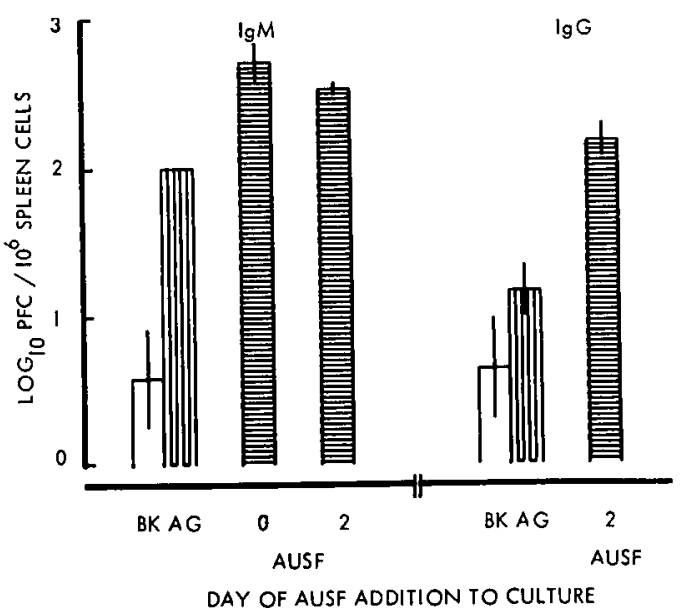

Fig. 1. Effect of time of addition of polyadenylic:polyuridylic acid (poly A:U)-induced thymocyte supernatant fluids (AUSF) to primary spleen cell cultures. Normal $F_{1}$ thymocytes $\left(1.0^{7} / \mathrm{ml}\right)$ were incubated with (AUSF) or without (control supernatant fluid; CSF) $50 \mu \mathrm{g} / \mathrm{ml}$ poly $\mathrm{A}: \mathrm{U}$ for $30 \mathrm{~min}$, washed four times, and cultured for $6 \mathrm{~h}$. Supernatant fluids were added at a 1:4 final dilution on day 0 or day 2 to cultures of normal $F_{1}$ spleen cells $\left(10^{7} / \mathrm{ml}\right)$ that received burro erythrocytes as antigen on day 0 . Direct and indirect plaque-forming cells (PFCs) were assayed on day 4. Mean $\log _{10} \mathrm{PFC} / 10^{6}$ viable recovered spleen cells $\pm S E$ from three normalized and pooled experiments are presented. All AUSF-stimulated groups (horizontal stripes) differed from background cultures (BK; open bars) and groups that received only antigen ( $A G$; vertical stripes) at $P<0.05$. As a positive control, $1.0 \mu \mathrm{g} / \mathrm{ml}$ poly $\mathrm{A}: \mathrm{U}$ added to culture with antigen stimulated IgM PFCs $\left(\log _{10} 2.78 \pm\right.$ $0.26)$ but not IgG PFCs $\left(\log _{10} 0\right)$.

the data from 17 experiments were normalized such that the average PFC response of spleen cells to BRBC alone was set at $100 \mathrm{PFC} 10^{6}$ viable recovered cells $\left(\log _{10} 2.00\right)$. This value was chosen because spleen cell cultures reproducibly responded with 50-150 $\mathrm{PFC}_{1} 10^{6}$ viable recovered cells when stimulated by this antigen alone. Responses of other groups within the same experiment were adjusted accordingly, and the average response value was determined for each like group. With this calculation, control supernatant fluids from unstimulated thymocytes had a mean value of $113 \pm 25$ $\left(\log _{10} 2.05\right)$, and AUSF-supplemented cultures had a threefold higher mean value of $305 \pm$ $61\left(\log _{10} 2.48\right)$, which is significantly different at $P<0.05$.

\section{Effect of delayed addition of AUSF to spleen cell cultures}

In several systems the induction or enhancement of $\mathrm{PFC}$ responses by $\mathrm{T}$-cell factors depends on the time of addition of factor and antigen $(1,9,21,25,27,31)$. We determined whether AUSF could stimulate PFC responses also when added to cultures 2 days after antigen. As can be seen in Fig. 1, addition of AUSF on day 2 enhanced both the IgM and the $\mathrm{IgG}$ responses as well as when added on day 0 . The increase in IgG PFCs, when AUSF was added on day 0 , was variable in these experiments and is not shown. The fact that late addition of AUSF enhanced both $\operatorname{IgM}$ and $\mathrm{IgG}$ PFCs suggests that AUSF may stimulate proliferation of activated lymphocytes.

One of the probable functions of the $\mathrm{T}$ cell in humoral immunity is to control IgG synthesis $(28,29)$, and since evidence has been presented that this cell is a major target of poly $A: U$ 's adjuvant action, the effect of AUSF on IgG synthesis was determined. It is apparent from Fig. 1 that AUSF augmented the IgG response in primary spleen cell cultures rather dramatically; poly $A: U$ added directly to the Mishell-Dutton culture system was not capable of exerting this effect.

\section{AUSF enbancement of secondary responses in vitro}

The relationship between the selective stimulation of $T$ cells by poly $A: U$ and $T$-cell control of IgG synthesis suggested that a product of poly A:U-stimulated $T$ cells might also stimulate secondary PFC responses. Accordingly, AUSF was added with antigen to cultures of syngeneic spleen cells from mice that had been primed with $4-8 \times 10^{8} \mathrm{BRBC}$ at least 3 weeks previously. Four days later IgM and IgG PFCs were assayed. Little residual response remained in the primed spleen cell population at this time, inasmuch as the IgM and IgG PFC responses of the primed spleen cells were lower before culture than the responses seen subse- 
Table III. Enhancement of secondary plaque-forming cell (PFC) responses by polyadenylic:polyuridylic acid (poly $A: U$ )-induced thymocyte supernatant fluids (AUSF)

\begin{tabular}{|c|c|c|}
\hline \multirow{2}{*}{$\begin{array}{c}\text { Primed } \\
\left(\mathrm{C} 57 \mathrm{Bl} / 6 \times \mathrm{C}_{3} \mathrm{Hf}\right) \mathrm{F}_{1} \\
\text { spleen cells }\left(10^{7}\right) \text { plus }\end{array}$} & \multicolumn{2}{|c|}{$\begin{array}{c}\text { Mean } \log _{10} \mathrm{PFC} / 10^{6} \\
\text { viable recovered spleen cells }\end{array}$} \\
\hline & $\operatorname{Ig} M$ & $\operatorname{IgG}$ \\
\hline Nothing (control) & $1.65(45)$ & $1.99(98)$ \\
\hline $\mathrm{BRBC}^{*}$ & $2.60(400)$ & $3.12(1326)$ \\
\hline $\mathrm{BRBC}+1.0 \mu \mathrm{g}$ poly $\mathrm{A}: \mathrm{U}$ & $3.38(2408)$ & $3.25(1816)$ \\
\hline $\mathrm{BRBC}+\mathrm{CSF} \dagger$ & $2.66(463)$ & $3.43(2691)$ \\
\hline $\mathrm{BRBC}+\mathrm{AUSF} \dagger$ & $3.25(1793)$ & $3.74(5576)$ \\
\hline
\end{tabular}

* $\mathrm{BRBC}=$ burro erythrocytes.

$\dagger$ Normal $F_{1}$ thymocytes $\left(10^{7} / \mathrm{ml}\right)$ were incubated with (AUSF) or without (control supernatant fluid; CSF) $50 \mu \mathrm{g} / \mathrm{ml}$ poly $A: U$ for $30 \mathrm{~min}$, washed four times, and cultured for $6 \mathrm{~h}$. Supernatant fluids were added to cultures of BRBC-primed $F_{1}$ spleen cells $\left(10^{7} / \mathrm{ml}\right)$ at a $1: 4$ final dilution with $B R B C$ as antigen on day 0 . PFCs were assayed on day 4. Mice were primed with a single injection of $4 \times 10^{8}$ BRBC 3 weeks before use. Results of one representative experiment are shown. Antilog PFC values are shown in parentheses. quently in background cultures. The data presented in Table III show that AUSF stimulated both IgM and IgG secondary PFC responses to above an already elevated response stimulated by antigen alone. AUSF caused a two- to fourfold increase in IgM PFCs compared with groups receiving control supernatant fluid (CSF) and antigen or antigen alone. IgG PFCs also were increased two- to four-fold higher than groups that received only antigen and twofold higher than CSF-supplemented cultures. CSF did not stimulate detectable secondary IgM PFCs but caused a twofold increase in IgG PFCs in the experiment shown.

\section{Poly A:U stimulation of peripheral lymphoid tissue to produce soluble enbancing factors}

To determine whether poly A:U could stimulate $\mathrm{T}$ cells in peripheral lymphoid tissue, as well as thymocytes, to produce soluble enhancing factors, spleen cells were incubated with or without poly $A: U$ for $30 \mathrm{~min}$, washed four times, and cultured for $6 \mathrm{~h}$. Supernatant fluids, harvested as before, were assayed in the usual manner along with AUSF prepared from

Table IV. Comparison of plaque-forming cell (PFC)-enhancing supernatant fluids (AUSF) from polyadenylic:polyuridylic acid (poly A:U)-activated spleen and thymus lymphocytes

\begin{tabular}{|c|c|c|c|}
\hline \multirow{2}{*}{ Group } & \multirow{2}{*}{$\begin{array}{c}(\mathrm{C} 57 \mathrm{Bl} / 6 \times \mathrm{C} 3 \mathrm{Hf}) \mathrm{F}_{1} \\
\text { spleen cells }\left(10^{7}\right) \text { plus* }\end{array}$} & \multicolumn{2}{|c|}{$\begin{array}{c}\text { Mean } \log _{10} \mathrm{PFC} / 10^{6} \\
\text { viable recovered spleen cells }\end{array}$} \\
\hline & & $\mathrm{PFC} \dagger$ & $P$ \\
\hline 1 & Nothing (control) & $1.40 \pm 0.11(25)$ & $<0.05^{* *}$ \\
\hline 2 & BRBC & $2.00 \pm 0 \quad(100)$ & \\
\hline 3 & $\mathrm{BRBC}+1.0 \mu \mathrm{g} / \mathrm{ml} \mathrm{A}: \mathrm{U}$ & $2.82 \pm 0.09(660)$ & $<0.001^{* *}$ \\
\hline 4 & $\mathrm{BRBC}+$ thymus $\mathrm{CSF}$ & $2.06 \pm 0.02(115)$ & n.s. ${ }^{* *}$ \\
\hline 5 & BRBC + thymus AUSF & $2.55 \pm 0.07(349)$ & $<0.05 t \dagger$ \\
\hline 6 & $\mathrm{BRBC}+$ spleen CSF & $2.19 \pm 0.03(154)$ & n.s. ${ }^{* *}$ \\
\hline 7 & BRBC + spleen AUSF & $2.52 \pm 0.10(331)$ & $<0.05^{* * * *}$ \\
\hline
\end{tabular}

* Normal $F_{1}$ thymus or spleen cells $\left(10^{7} / \mathrm{ml}\right.$ ) were incubated with (AUSF) or without (control supernatant fluid; CSF) poly A:U $(50 \mu \mathrm{g} / \mathrm{ml})$ for $30 \mathrm{~min}$, washed four times, and cultured for $6 \mathrm{~h}$. Harvested supernatant fluids were added to cultures of normal $F_{1}$ spleen cells at a 1:4 final dilution with burro erythrocytes (BRBC) on day 0 .

$\dagger$ Direct PFCs were assayed on day 4. Results from three normalized and pooled experiments are presented. Antilog PFC values are shown in parentheses.

** Compared with group 2 ; n.s. = not significant.

$\dagger+$ Compared with groups 2 and 4.

*** Compared with groups 2 and 6. 
Table V. Failure of polyadenylic:polyuridylic acid (poly A:U)-induced supernatant fluid (AUSF) to stimulate T-cell-depleted spleen cells

\begin{tabular}{|c|c|c|c|}
\hline \multirow[t]{2}{*}{ Group } & \multirow[t]{2}{*}{$\begin{array}{c}\left(\mathrm{C} 57 \mathrm{Bl} / 6 \times \mathrm{C}_{3} \mathrm{Hf}\right) \mathrm{F}_{1} \text { spleen } \\
\text { cells }\left(10^{7}\right) \text { plus }^{*}\end{array}$} & \multicolumn{2}{|c|}{$\begin{array}{l}\text { Mean } \log _{10} \operatorname{IgM} P F C / 10^{6} \text { viable } \\
\text { recovered spleen cells }\end{array}$} \\
\hline & & $\mathrm{PFC} \dagger$ & $P$ \\
\hline \multicolumn{4}{|c|}{ Normal spleen cells } \\
\hline 1 & Nothing (control) & $1.09 \pm 0.20(12)$ & $<0.05^{* *}$ \\
\hline 2 & $\mathrm{BRBC}$ & $2.00 \pm 0 \quad(100)$ & \\
\hline 3 & $\mathrm{BRBC}+$ poly $\mathrm{A}: \mathrm{U}(1.0 \mu \mathrm{g} / \mathrm{ml})$ & $2.57 \pm 0.09(372)$ & $<0.05^{* *}$ \\
\hline 4 & $\mathrm{BRBC}+\mathrm{LPS}(0.1 \mu \mathrm{g} / \mathrm{ml})$ & $2.21 \pm 0.01(163)$ & $<0.05^{* *}$ \\
\hline 5 & $\mathrm{BRBC}+\mathrm{CSF}$ & $2.01 \pm 0.06(102)$ & n.s.** \\
\hline 6 & $\mathrm{BRBC}+\mathrm{AUSF}$ & $2.50 \pm 0.06(316)$ & $<0.05 \dagger \dagger$ \\
\hline \multicolumn{4}{|c|}{ Anti-theta-treated spleen cells } \\
\hline 7 & Nothing (control) & $0.3 \pm 0.3$ & n.s.*** \\
\hline 8 & BRBC & $0.91 \pm 0.18(8)$ & \\
\hline 9 & $\mathrm{BRBC}+$ poly $\mathrm{A}: \mathrm{U}(1.0 \mu \mathrm{g} / \mathrm{ml})$ & $1.27 \pm 0.43(19)$ & n.s.*** \\
\hline 10 & BRBC + LPS $(0.1 \mu \mathrm{g} / \mathrm{ml})$ & $2.06 \pm 0.08(115)$ & $<0.05^{* * * *}$ \\
\hline 11 & $\mathrm{BRBC}+\mathrm{CSF}$ & $1.29 \pm 0.10(20)$ & n.s.*** \\
\hline 12 & BRBC + AUSF & $0.67 \pm 0.33(5)$ & n.s. ${ }^{* * * *}$ \\
\hline
\end{tabular}

* Cultures of normal or anti-theta- and complement-treated $F_{1}$ spleen cells received control supernatant fluid (CSF) or AUSF at a 1:4 final dilution with burro erythrocytes (BRBC) on day 0. Other groups received lipopolysaccharide (LPS) or poly A:U and BRBC.

$\dagger$ Direct plaque-forming cells (PFCs) were assayed on day 4. Results from 3 normalized and pooled experiments are presented. Antilog PFC values are shown in parentheses.

t† Compared with groups 2 and 5.

*** Compared with group 8 .

thymocytes. It was found (Table IV) that the degree of PFC enhancement by spleen cell AUSF was equivalent to that of thymocyte AUSF, suggesting that AUSF may be a product of a relatively mature $\mathrm{T}$-cell population. Whether poly A:U activated cells other than $\mathbf{T}$ cells in the spleen cell population could not be determined from this experiment.

\section{Failure of AUSF to reconstitute $T$-cell-deficient spleen cell cultures}

T-cell-depleted spleen cell cultures were prepared by treatment of normal cells with anti-theta antiserum and GPC. AUSF was prepared from syngeneic thymocytes as before and added to cultures of normal or anti-thetatreated spleen cells at a 1:4 final dilution with antigen on day 0 . PFCs were assayed 4 days later. Data presented in Table $\mathrm{V}$ indicate that, whereas AUSF enhanced IgM PFCs in cultures of normal spleen cells, no such increase oc- curred in T-cell-depleted cultures. Furthermore, LPS, added as a positive control, stimulated IgM PFC formation in normal and T-celldepleted cultures, indicating that the B-cell population was capable of responding. Poly A:U stimulated only cultures of normal spleen cells ( $\log _{10}$ mean $2.57 \pm 0.09$, not shown).

A similar experiment, using nude spleen cells on a Balb/c background as a source of T-celldeficient spleen cells reaffirmed the inability of AUSF, from syngeneic thymocytes, to replace $T$-cell function (data not shown). In a second experiment, using a potent AUSF preparation from $F_{1}$ thymocytes, there was no stimulation of PFC formation in cultures of spleen cells from Balbic nude mice.

\section{Quantitation of poly A:U content in AUSF}

To determine the amount of residual poly A:U in AUSF, radiolabeled polynucleotide complexes were used to trace the fate of poly A:U after thymocyte stimulation. 
Normal $F_{1}$ thymocytes $\left(10^{7} / \mathrm{ml}\right)$ were incubated with $50 \mu \mathrm{g} / \mathrm{ml}{ }^{3} \mathrm{H}$-labeled poly A:U $(61,350 \mathrm{cpm} / 50 \mu \mathrm{g} / \mathrm{ml})$ for $30 \mathrm{~min}$, washed four times, and cultured for $6 \mathrm{~h}$. After culture, two centrifugations were performed, and the resultant supernatant fluids were filter-sterilized and assayed for radioactive poly $A: U$ content. AUSF produced in these experiments was shown to significantly enhance IgM PFCs. The results (Fig. 2) show that essentially all poly $A: U$ is removed in the first wash. Negligible . radioactivity appeared in AUSF, equivalent to $0.03 \pm 0.01 \mu \mathrm{g} / \mathrm{ml}$ poly A:U. This is $30-$ to 60 -fold less than the lowest concentration of poly A:U necessary to enhance PFC formation in our culture system. $48.59 \pm 1.19$ of the original $50 \mu \mathrm{giml}$ poly A:U could be accounted for. Consequently, stimulatory amounts of poly A:U were not present in AUSF.

\section{DISCUSSION}

The data presented here demonstrate that poly $A: U$ stimulation of normal mouse thymocytes effects the early release of soluble PFC-enhancing factors into a medium free of both antigen and serum. This finding clarifies and extends earlier observations that the adjuvant action of poly $\mathrm{A}: \mathrm{U}$ was associated with a decreased induction period of the immune response without any significant mitogenic action on $\mathrm{T}$ cells (16). Thus, it appears that the function, rather than the numbers, of $T$ cells is amplified by this adjuvant. Control supernatant fluids from nonstimulated thymocytes were able to stimulate IgM PFC responses as effectively as AUSF, but only when the cells producing the factor were cultured for a longer period of time. A similar finding with regard to CSF has been reported by Doria et al. (8). The finding that a factor was found in the supernatant fluids as early as 10 min after exposure to poly $A: U$ and $6 \mathrm{~h}$ in culture is also in contrast to the $24-48 \mathrm{~h}$ required for the production of T-cell factors induced after antigenic, mitogenic, or allogeneic stimulation. Poly A:U thus hastens the release of what may be a normally occurring physiologically active T-cell product.

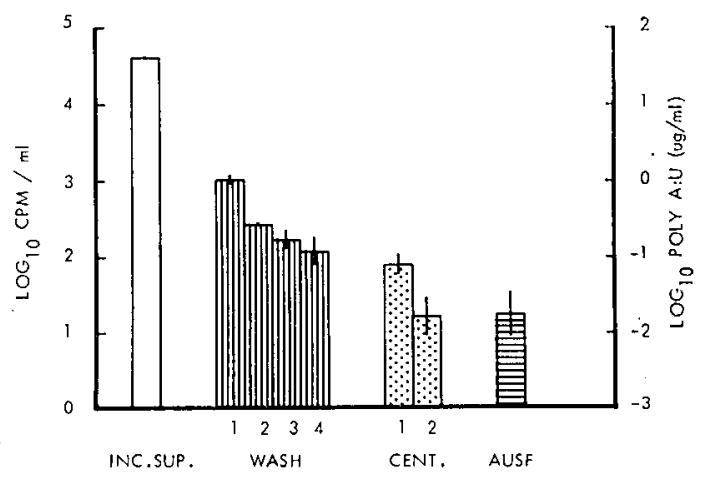

Fig. 2. Polyadenylic:polyuridylic acid (poly A:U) content in poly A:U-induced supernatant fluid (AUSF). Normal $F_{1}$ thymocytes $\left(10^{7} / \mathrm{ml}\right)$ were incubated with $50 \mu \mathrm{g} / \mathrm{ml}$ of ${ }^{3} \mathrm{H}$-labeled poly $\mathrm{A}: \mathrm{U}$ $(61,350 \mathrm{cpm} / 50 \mu \mathrm{g} \mathrm{A}: \mathrm{U} / \mathrm{ml})$ for $30 \mathrm{~min}$, washed four times, and cultured for $6 \mathrm{~h}$. After culture, two centrifugations were performed, and the resultant supernatant fluids were sterile-filtered and assayed for radioactive content. Data from triplicate samples of the supernatant fluids from the centrifugation after the initial incubation (open bars), washes 1 through 4 (vertical stripes), two centrifugations after $6 \mathrm{~h}$ in culture (stippled bars), and filtered AUSF (horizontal stripes) are presented as the mean $\log _{10} \mathrm{cpm} /$ $\mathrm{ml} \pm \mathrm{SE}$. The right-hand ordinate indicates poly $\mathrm{A}: \mathrm{U}$ content. $48.59 \pm 1.19$ of the original $50 \mu \mathrm{g} /$ $\mathrm{ml}$ poly A:U were recovered. AUSF contained 0.03 $\pm 0.01 \mu \mathrm{g} / \mathrm{ml}$ poly $\mathrm{A}: \mathrm{U}$.

Several stimulatory T-cell factors have been reported to be effective over a narrow time range, usually the first $24 \mathrm{~h}$ of culture, for optimal activation of PFC responses $(14,21$, 24, 30). In our experiments, enhancement of primary IgM and/or IgG PFC responses was observed regardless of whether AUSF was added with antigen at the initiation of the culture period or $48 \mathrm{~h}$ later, indicating that AUSF may stimulate proliferative instead of inductive functions. It may be argued that AUSF, added initially, may persist in the culture milieu until a later responsive period by binding to antibody-forming precursor cells, as has been proposed for the factor described by Gorczynski et al. (14). For secondary in vitro responses, also only a single addition of AUSF at culture initiation was necessary. Schimpl \& Wecker (26) have reported that to stimulate secondary responses, their $\mathrm{T}$-cell 
replacing factor needed to be added daily, whereas Amerding \& Katz (1) found that only one addition of their factor at culture initiation was sufficient. These discrepancies may reflect minor differences in factor stability and concentration or may be due to distinct activities of the respective factors.

The enhancement induced by AUSF was twice that reported for supernatant fluids from antigen-primed spleen cells that had been reexposed to the priming antigen in vitro and may be the result of poly $A: U$ polyclonally stimulating a larger percentage of the thymocyte population than would occur in a clonally restricted, antigen-induced response (21).

AUSF stimulation of PFC responses was modest (threefold greater than with antigen alone). However, it should be noted that AUSF enhancement occurred in cultures of normal spleen cells that were capable of mounting a strong PFC response without AUSF. Therefore, AUSF should not be expected to stimulate PFC formation to the degree seen in $\mathrm{T}$-cell-deficient cultures that had been reconstituted by soluble T-cell factors $(1,14,24,27)$.

Since cell dilution studies have demonstrated that $\mathrm{T}$ cells are limiting in the Mishell-Dutton system (17), AUSF may have exerted its effect on $T$ cells. This is supported by the fact that AUSF was successful at initiating a primary IgG PFC response in culture, a T-cell-dependent event. Indeed, in light of the failure of AUSF to reconstitute cultures of anti-thetatreated or nude spleen cells, its enhancing action must be considered to be dependent on the presence of $T$ cells. Gorczynski et al. (14) have reported a $T$-cell factor that required a small population of $\mathrm{X}$-irradiated $\mathrm{T}$ cells to supply an auxiliary function in the stimulation of anti-theta-treated spleen cells. Schimpl \& Wecker (24) and Armerding \& Katz (2) have reported T-cell factors capable of enhancing PFC responses but incapable of substituting for $\mathrm{T}$ cells. Thus, some $\mathrm{T}$-cell factors act in concert with other T-cell helper functions. It is not known as yet whether AUSF acts on T cells or whether it may affect the induction and/or proliferation of $\mathrm{B}$ cells, either directly or via macrophages. If $B$ cells are the target of stimu- lation, AUSF's demonstrated requirement for accessory $T$ cells presumably would be for normal helper $\mathrm{T}$ cells. Further experiments are underway to establish more definitely the cel. lular site of action of AUSF.

Variation in the amount of AUSF activity, and its action on IgM and/or IgG PFC responses, was apparent throughout this study. For example, approximately $25 \%$ of the early experiments, where IgM alone was measured, were negative. However, in further studies it appeared that induction of IgG PFC in primary cultures was a more stable indicator.

Preliminary characterization of AUSF has revealed that it is trypsin-sensitive, nondialyzable, and resistant to mild heat treatment. Whereas AUSF activity may have been presumed initially to be simply due to poly $A: U$ leached from the thymocytes during culture, three points of evidence argue against this possibility: (a) thymocyte cultures that received poly A:U but were not incubated showed no significant AUSF activity; (b) poly $A: U$ added directly to cultured spleen cells with antigen rarely induced IgG PFC, whereas AUSF did so consistently; and (c) experiments using radioisotopically labeled poly $A: U$ confirmed the lack of functional amounts of poly $A: U$ in the supernatant fluids.

T-cell stimulation by poly A:U has been well documented (18), and the evidence suggests that poly A:U's main mode of adjuvant action is through the stimulation of these cells. Hamaoka \& Katz (15) demonstrated that spleen cells from donors primed with dinitrophenyl-keyhole limpet hemocyanin could respond to dinitrophenyl on the heterologous carrier, bovine gammaglobulin (BGG), in the presence of poly $A: U$. Poly A:U stimulation of this response was abrogated by pretreatment of the donor spleen cell population with antitheta antiserum and complement, demonstrating the T-cell locus of stimulation. Since poly A:U failed to augment the adoptive secondary response when the hapten was linked to a nonimmunogenic copolymer of D-glutamic acid and D-lysine (D-G,L), for which few or no specific $T$ cells could be demonstrated, it was concluded that poly $\mathrm{A}: \mathrm{U}$ activated a population 
of BGG-specific, unimmunized $T$ cells in the donor cell population. However, as is suggested in the present manuscript, poly $A: U$ activates thymocytes and peripheral lymphoid $T$ cells in the absence of antigen and FCS to produce supernatant fluids with nonspecific enhancing activity. Thus, T-cell factor release caused by poly $A: U$ is most likely polyclonal, but the expression of nonspecific enhancement by AUSF may be dependent on an undetermined antigenspecific function of $\mathrm{T}$ cells. The hypothesis that the adjuvant mechanism of poly $A: U$ is the result of polyclonal $\mathrm{T}$-cell stimulation resulting in the elaboration of active soluble factors is consistent with recent findings that poly $\mathrm{A}: \mathrm{U}$ (10) or AUSF (11) blocks the induction of tolerance to soluble $\mathrm{BGG}$ in vivo.

\section{ACKNOWLEDGEMENTS}

This work was supported by grant AM 14273 from the U.S. Public Health Service, National Institutes of Health. P. H. Bick was a recipient of U.S. Public Health Service Training Grant 5 TO 1 GM02204.

\section{REFERENCES}

1. Amerding, D. \& Katz, D. H. Activation of T and B lymphocytes in vitro. II. Biological and biochemical properties an allogeneic effect factor (AEF) active in triggering specific B lymphocytes. J. Immunol. 140, 19, 1974.

2. Amerding, D. \& Katz, D. H. Activation of $T$ and $B$ lymphocytes in vitro. IV. Regulatory influence on specific $T$ cell functions by a thymus extract fatcor. J. Immunol. 114, 1248, 1975.

3. Cone, R. E. \& Johnson, A. G. Regulation of the immune system by synthetic polynucleotides. III. Action on antigen-reactive cells of thymic origin. J. exp. Med. 133, 655, 1971.

4. Cone, R. E. \& Johnson, A. G. Regulation of the immune system by synthetic polynucleotides. IV. Amplification of proliferation of thymus-influenced lymphocytes. Cell. Immunol. 3, 283, 1972.

5. Cone, R. E. \& Marchalonis, J. J. Adjuvant action of poly A:U on $T$ cells during the primary immune response in vitro. Aust. J. exp. Biol. Med. Sci. 50, 69, 1972.

6. Coutinho, A., Möller, G., Andersson, J. \& Bullock, W. W. In vitro activation of mouse lymphocytes in serum-free medium: effect of $T$ and $B$ cell mitogens on proliferation and antibody synthesis. Europ. J. Immunol. 3, 299, 1973.
7. Coutinho, A., Möller, G. \& Richter, W. Molecular basis of B-cell activation. I. Mitogenicity of native and substituted dextrans. Scand. J. Immunol. 3, $321,1974$.

8. Doria, G., Agarossi, G. \& DiPietro, S. Enhancing activity of thymocyte culture cell-free medium in the in vitro immune response of spleen cells from neonatally thymectomized mice to sheep RBC. J. Immunol. 108, 268, 1972.

9. Dutton, R. W. \& Hunter, P. The effects of mitogen stimulated $\mathrm{T}$ cells on the response of $B$ cells to antigen and the mechanism of $T$ cell stimulation of the $B$ cell response. in Edelman, E. G. (ed.) Cellular Selection and Regulation in the Immune Response. Raven Press, New York, 1974.

10. Fessia, S. L. \& Kong, Y. M. Studies on interference with tolerance induction in $\mathrm{T}$ cells. Scand. J. Immunol. 6, 1977. In press.

11. Fessia, S. L., Kong, Y. M., Bick, P. H. \& Johnson, A. G. Prevention of tolerance induction to a thymus-dependent antigen by poly $A: U$. induced thymocyte fluid. Europ. J. I mmunol. 8, 508, 1977.

12. Friedman, H. Thymus factors in immunity. $A n n$. N.Y. Acad. Sci. 249, 61, 1975.

13. Gorczynski, R. M., Miller, R. G. \& Phillips, R. A. Specific immunosuppression of antibody responses by an antiserum against a $T$-cell factor. Transplant. Proc. 5, 607, 1973.

14. Gorczynski, R. M., Miller, R. G. \& Phillips, R. A. Reconstitution of $\mathrm{T}$ cell-depleted spleen cell populations by factors derived from $\mathrm{T}$ cells. III. Mechanism of action of $\mathrm{T}$ cell derived factors. J. Immunol. 111, 900, 1973.

15. Hamaoka, T. \& Katz, D. H. Mechanism of the adjuvant activity of poly $A: U$ on antibody responses to hapten-carrier conjugates. Cell. Immunol. 7, 246, 1973.

16. Han, I. H. \& Johnson, A. G. The mitogenic activity of polyadenylic-polyuridylic acid complexes. Ann. N.Y. Acad. Sci. 249, 370, 1975.

17. Hunter, P. \& Kettman, J. R. Mode of action of a supernatant activity from $T$-cell cultures that non-specifically stimulates the humoral response. Proc. nat. Acad. Sci. (USA) 71, 512, 1974.

18. Johnson, A. G. The adjuvant action of synthetic polynucleotides on the immune response. in Cohen, E. P. (ed.) Immune RNA. CRC Press, Cleveland, Ohio, 1976.

19. Mishell, R. I. \& Dutton, R. W. Immunization of dissociated spleen cell cultures from normal mice. J. exp. Med. 126, 423, 1966.

20. Reif, A. E. \& Allen, J. M. Mouse thymic isoantigens. Nature (Lond.) 209, S2 I, 1966.

21. Rubin, A. S. \& Coons, A. H. Specific heterologous enhancement of immune responses. III. Partial characterization of supernatant material with enhancing activity. J. Immunol. 108, 1597, 1972.

22. Ruhl, H., Vogt, W., Bochert, G. \& Diamantstein, 
T. Stimulation of B cells by poly A:poly $U$ and poly I:poly C in vitro. Immunology 26, 937, 1974.

23. Scher, I., Strong, D. M., Ahmed, A., Knudsen, R. C. \& Sell, K. W. Specific murine B-cell activation by synthetic single and double stranded polynucleoides. J. exp. Med. 138, 1545, 1973.

24. Schimpl, A. \& Wecker, E. Replacement of T cell function by a $\mathrm{T}$ cell product. Nature (New Biol.) $237,15,1972$.

25. Schimpl, A. \& Wecker, E. Studies on the source and action of the $T$ cell replacing factor (TRF). Advanc, exp. Biol. Med. 29, 179, 1973.

26. Schimpl, A. \& Wecker, E. Stimulation of $\mathrm{IgG}$ antibody responses in vitro by $\mathrm{T}$ cell replacing factor. J. exp. Med. 137, 547, 1973.

27. Sjöberg, O., Andersson, J. \& Möller, G. Reconstitution of the antibody response in vitro of $T$ cell-deprived spleen cells by supernatants from spleen cell cultures. J. Immunol. 109, 1379, 1972.
28. Taylor, R. E. \& Wortis, H. H. Thymus dependence of antibody response; variation with dose and class of antibody. Nature (Lond.) 220, 927, 1968.

29. Torrigiani, G. Quantitative estimation of antibody in immunoglobulin classes of the mouse. II. Thymic dependence of the different classes. $J$. Immunol. 108, 161, 1972.

30. Waldmann, H. \& Munro, A. T-cell dependent mediator in the immune response. II. Physical and biological properties. Immunology 27, 53, 1974.

31. Watson, J. The role of humoral factors in the initiation of in vitro primary immune responses. J. Immunol. 111, 1301, 1973.

32. Wecker, E., Schimpl, A., Hunig, T. \& Kuhn, L. A T-cell produced mediator substance active in the humoral response. Ann. N.Y. Acad. Sci. 249, $258,1975$.
Received 23 May 1977

Received in revised form 11 July 1977 
This document is a scanned copy of a printed document. No warranty is given about the accuracy of the copy. Users should refer to the original published version of the material. 